\title{
Contractor Monitoring and Performance of Road Infrastructure Projects in Uganda: A Management Model
}

\author{
Aloysius Byaruhanga1, Benon C. Basheka² \\ ${ }^{1}$ Mbarara University of Science and Technology, Mbarara, Uganda \\ ${ }^{2}$ Uganda Technology and Management University, Kampala, Uganda \\ Email: mwesigwabyaruhanga@gmail.com
}

How to cite this paper: Byaruhanga, A. and Basheka, B.C. (2017) Contractor Monitoring and Performance of Road Infrastructure Projects in Uganda: A Management Model. Journal of Building Construction and Planning Research, 5, 30-44. https://doi.org/10.4236/jbcpr.2017.51003

Received: January 23, 2017

Accepted: March 25, 2017

Published: March 28, 2017

Copyright $\odot 2017$ by authors and Scientific Research Publishing Inc. This work is licensed under the Creative Commons Attribution International License (CC BY 4.0).

http://creativecommons.org/licenses/by/4.0/

(c) (i) Open Access

\begin{abstract}
An understanding of the influence of contractor monitoring on performance of road infrastructural projects in Uganda provided an impetus for this study. The objectives of the study were to: assess the relationship between contractors monitoring and performance of national road infrastructure projects and the relationship between contractor monitoring components and performance of national road infrastructure projects in Uganda. Purposive sampling was employed in selecting the procurement professionals, engineers and simple random sampling was adopted in selecting private consultants, members of parliament and respondents from the civil society organizations. Data for this study were collected using a closed ended questionnaire and interviews. Some of the major finding from this study include: weak procurement rules which lead to awarding road projects to incompetent contractors; contractor monitoring being handled by unqualified, incompetent and inexperienced professionals; lack of contractors and contract supervisors appraisal system; delay of contractors payments which affects timelines in services delivery; lack of a strong internal project monitoring and evaluation mechanism at the Uganda National Roads Agency (UNRA). The research therefore recommends the establishment of an Independent Public Infrastructure Development and Monitoring Unit by government and adoption of systems that appraise both contractors and contract supervisors with clear disciplinary actions for unsatisfactory performance by the UNRA.
\end{abstract}

\section{Keywords}

Contractor Monitoring, Performance of Roads, Infrastructure Management, Uganda 


\section{Introduction}

Road infrastructure is a crucial driving force for economic growth in any country and sustained access to roads is essential to improve living standards [1]. According to [2] productivity, welfare, and security of both rural and urban people are greatly influenced by the level of road infrastructure development in any country. Production costs, employment creation, markets access, and investment depend on the quality of infrastructure, especially road transport [3].

Globally more governments are placing greater emphasis on the development of infrastructure projects [4]. The demand for global infrastructure spending has been projected between $\$ 40$ trillion and $\$ 50$ trillion over the next two decades.

Unlike the United States, studies in countries spanning the entire range of economic development have also revealed positive improvements in infrastructure development [5]. European Union estimates up to $\$ 2.7$ trillion shall be required through 2020 to meet the current goals for new infrastructure spending [6].

In Africa, although use of roads dominates the transport sector, carrying $80 \%$ to $90 \%$ of passenger and freight traffic in most countries, the condition of these roads remains very poor by international standards [7]. The World Bank report of 2011 indicates that Africa has the lowest spatial density of roads than any other region of the world, only $204 \mathrm{~km}$ of roads per $1000 \mathrm{~km}^{2}$ of land area, with only one-quarter paved, while the world average is $944 \mathrm{~km} / 1000 \mathrm{~km}^{2}$, with over half paved [8]. The spatial density of Sub-Saharan Africa's roads is less than 30 percent of that of South Asia, where half of the roads are paved, and only 6 percent of that of North America, where two-thirds are paved [9]. In order to respond to this challenge, the World Bank report of 2011 proposes that the African road sector has passed through a wide ranging policy reforms, with most countries embarking on creation of independent source of funding for road maintenance based on road-user charges. [10] however, assert that the reforms have not fully improved the performance of roads in Africa.

The Government of Uganda for example, instituted reforms in the road sector in 1996, due to the importance attached to road infrastructure. These reforms culminated into the creation of Road Agency Formation Unit (RAFU) in 1998, and eventual establishment through the Act of Parliament, Uganda National Roads Authority (UNRA). UNRA replaced the RAFU as an autonomous body mandated to develop and maintain the National Road network. UNRA became operational on $1^{\text {st }}$ July 2008 and as part of the key functions it was mandated to select contractors for road works, monitor road construction and ensure effective performance of road projects [11].

In spite of the reforms and increased funding for the road sector from Uganda shillings 374.12 billion in 2005/06 to Uganda shillings 1214.82 billion in 2009/10, there has been inadequate improvement of service indicators for the sector [12]. Reports on performance of the road sector continue to indicate that the government is still losing billions of shillings in shoddy works and services [13]. The success attained by UNRA notwithstanding, the goal to optimize the quality, 
timeliness, cost effectiveness in road delivery so as to guarantee safe and efficient movement of people is still difficult to achieve [14]. There are still rampart delays in implementation of road works contracts, which is estimated to cost the tax payer over 2.5 billion per month. Many awarded road projects have delayed at implementation, and those launched have faced cost overruns and complaints of poor quality of works [15]. There are cases of incomplete or collapsing road infrastructure projects soon after commissioning OF these roads which is attributed to weak supervision [16] [17] indicate over 50 road projects in Uganda were either delayed or poorly constructed. Identification of the factors affecting performance of road infrastructure projects in Uganda therefore is very crucial if service delivery is to improve.

The study sought to examine the influence of contractor monitoring on performance of road infrastructure projects in Uganda taking into consideration the key components in contractor monitoring. The findings of this research will enable scholars, practitioners and policy makers appreciate the key contractor monitoring components that influence performance of road infrastructure projects.

\section{Objectives of the Study}

The objectives of the study were to:

1) assess the relationship between contractors monitoring and performance of national road infrastructure projects

2) assess the relationship between contractor monitoring components and performance of national road infrastructure projects in Uganda.

\section{Conceptual Framework}

\section{Independent Variable}

Contractor monitoring
- Competence of monitoring staff
- Communication of expectations
- Contractor performance appraisal
- - Timelyte monitoring
- Contractors capacity
- Timely compensation of PAP
- Design appropriateness
- Dispute resolution
- Constant feedback

Source: Researcher
Dependent

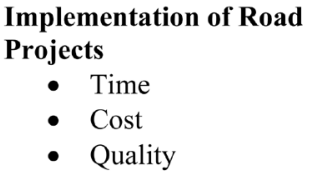

The Government Uganda has for several years' prioritized road infrastructure investment so as to unlock constraints to socio-economic transformation of the economy. According to [18] Government of Uganda in the Financial Year 2015/ 2016 released about UGX 3 trillion to Uganda National Roads Authority (UNRA) for road projects. Despite the high investments, the general state and quality of 
the roads across the country still requires a lot of improvement [19]. The public alleges that Uganda National Roads Authority (UNRA) has projects cost overruns, contract variations, delays, failure to compensate persons affected by projects, high levels of corruption, incompetence of contractors; and generally poor contractor monitoring. The recent revelations at the Commission of Inquiry into the alleged mismanagement, abuse of office at the Uganda National Roads Authority depicted gross irregularities in procurements, contract management, inflated costs of land compensation and delays in land acquisition to mention a few. Poor supervision and management of contracts; the awarding of contracts to incompetent Contractors unable to complete work in time; and unexplained delays in processing contractors' payments are still rampant in spite of the issues raised in the inquiry and continue to affect road project costs and schedules. Poor quality roads have continued to be the norm in Uganda, with the practitioners accusing one another for poor performance.

The researcher notes that despite the earlier studies in contract management and project performance [20], the specific reasons for poor quality road works, delayed completion of road projects and cost overruns on road infrastructure projects in Uganda continue to elude the project implementers. Billions tax payers' money continue to be lost on many road projects [21].

\section{Research Problem and Methodology}

The enactment on the Public Procurement and Disposal of Public Assets Authority (PPDA) Act of 2003, resulted into decentralization of the procurement and disposal function. Among the activities that were left to the Public Procurement Entities is management of project implementation. Despite the PPDA Act and the Regulations spelling out clearly the required procedures and regulatory framework for managing project implementation in Uganda, signs of improvement have been minimal. Procurement audits sanctioned by in public entities especially those handling public infrastructure such as roads have continuously shown that project monitoring is not given adequate attention. In 2006 the road sector in Uganda, underwent reforms aimed at ensuring timely delivery in the road sector. Key in the reforms was the creation of Uganda National Roads Authority (UNRA) a semi-autonomous institution with a mandate to procure contractors for national roads construction and maintenance [22].

However, there has been no commensurate improvement in the "success" rate of the road projects [23]. Poor quality roads have continued to be the norm in Uganda, with the practitioners accusing one another for poor performance. The researcher notes that despite the studies and efforts made to contract management and project performance [24], the specific reasons for poor quality road works, delayed completion of road projects and cost overruns on road infrastructure projects in Uganda continue to elude the project implementers. If the key components that make up a successful contract monitoring and hence project success continue to be taken lightly, government will continue losing billions of shillings in failed or poorly executed projects. 
The study was carried in Kampala district the capital city of Uganda because that where the largest number of key players who participate in the procurement and monitoring construction of road infrastructure are found. The study targeted four groups of respondents namely, project engineers, procurement professionals, members of contractors associations and members of civil society organisations, because they are directly involved in procurement and monitoring construction of road infrastructure

Purposive sampling was employed to select the procurement professionals, engineers while simple random sampling was adopted in selecting private consultants, members of parliament and respondents from the civil society organizations. Interviews were used to collect views from the key respondents, while data was collected using a questionnaire and analyzed using the Statistical Package for Social Scientists (SPSS).

\section{Data Analysis}

The analysis of data presented is based on information provided by respondents who included procurement practitioners and other key players closely involved in public procurement development. A questionnaire was administered by the researcher to 190 respondents and 172 questionnaires were received giving a response rate of $90.5 \%$. The analysis is therefore based on the 172 questionnaires received.

Table 1 shows that $59.3 \%$ of the respondents were in the age group (30 - 40 years). Of the 172 respondents, $69.8 \%$ were male and $30.2 \%$ were female. Majori-

Table 1. Demographic characteristics.

\begin{tabular}{ccc}
\hline Age (Years) & Frequency & Percent (\%) \\
\hline $20-30$ & 16 & 9.3 \\
$30-40$ & 102 & 59.3 \\
Above 40 & 54 & 31.4 \\
Gender & & \\
Female & 52 & 30.2 \\
Male & 120 & 69.8 \\
Education & & \\
Certificate & 34 & 19.8 \\
Diploma & 32 & 18.6 \\
Bachelor's Degree & 80 & 46.5 \\
Masters Degree & 26 & 15.1 \\
Occupation & & \\
Procurement Professionals & 100 & 58.1 \\
Private Consulting Engineers & 9 & 5.2 \\
Project Engineers & 29 & 16.9 \\
Contractors & 12 & 6.9 \\
Total & 13 & 7.6 \\
Members of Parliament on Infrastructure Committee & 9 & 5 \\
Members of Civil Society Organization & 172 & 100 \\
\hline
\end{tabular}


ty of the respondents had attained a Bachelor's degree (46.5\%) and only $15.1 \%$ had attained a Master's degree and majority of the respondents were procurement professionals $(58.1 \%)$. Therefore, the results indicate that majority of the respondents had attained good education and desired skills and knowledge and therefore are able to deliver.

The results as presented in the above Table 2 indicate a high degree of rating of almost all the items that measured contractor monitoring based on the mean scores which were all above 3 on the basis of a maximum score of 5 since the survey instrument had a 5 Likert scale. This is supported by the high percentage scores on those who agreed with each of the statements. The quantitative results presented above reflect the perception of the respondents. However, there are findings from interviews and documentary reviews that give the status of contractor monitoring and how it influences the performance of road infrastructure projects.

\section{Basing on Survey Findings}

It was further established that $90.6 \%$ of the respondents agreed that staff designated to monitor contractors lacked adequate supervisory skills. This probably explains why some roads get into a bad state within a few months after construction. The roads according to respondents were Oluyo-Packwach-Arua Road, Entebbe road, Kampala-Jinja Road, Tororo-Mbale-Soroti, Kampala-Masaka etc. On whether UNRA had approved procedures in place for contractor monitoring, $86.9 \%$ inclined to agreement. One of the respondents noted that: "The general public is not happy because there are a lot of delays in road projects in spite of the existence of monitoring procedures".

Furthermore, majority of the respondents (80.5\%) indicated that contractor performance appraisal was not being done during the project implementation.

Table 2. Descriptive statistics for contractor monitoring.

\begin{tabular}{|c|c|c|c|}
\hline Item measures for Contractor Monitoring & Mean & SD & Agreement \\
\hline lack of adequate supervisory skills to monitor contracts & 4.5 & 0.71 & $90.6 \%$ \\
\hline Approved procedures in place for contractor monitoring & 4.1 & 0.69 & $86.9 \%$ \\
\hline Contract supervisors do not prepare monitoring plans & 3.9 & 0.67 & $72.3 \%$ \\
\hline Project expectations are not clearly communicated to contractors & 4.1 & 0.59 & $77.7 \%$ \\
\hline $\begin{array}{c}\text { Contract performance appraisal is done } \\
\text { during project implementation. }\end{array}$ & 1.9 & 0.37 & $19.5 \%$ \\
\hline There is poor record management on road projects & 4.6 & 0.93 & $94.0 \%$ \\
\hline There is no timely payment of contractors & 3.8 & 0.78 & $71.1 \%$ \\
\hline No clear dispute resolution procedures for road projects & 4.9 & 0.22 & $96.3 \%$ \\
\hline No regular site inspections on road projects & 3.7 & 0.51 & $70.7 \%$ \\
\hline Technical audits are conducted during project implementation & 2.3 & 0.67 & $31.2 \%$ \\
\hline $\begin{array}{l}\text { No clear feedback mechanism between the } \\
\text { contractor and employer on road projects }\end{array}$ & 4.2 & 0.56 & $91.5 \%$ \\
\hline
\end{tabular}


One respondent mentioned that" contractor performance appraisal is done during project implementation and not in all agencies, but in some few". The private consultants $(57 \%)$ on the other hand had mixed responses about contractor performance appraisal being done during project implementation. They felt that the management of some public entities takes over the process hence overshadowing the contractor performance appraisal exercise.

On regular site inspection, findings further revealed that $70.7 \%$ of the respondents agreed that there are no regular on site inspections on road projects. One of the respondents noted that "at the beginning stage, the procedure for contractor monitoring should be agreed on between the contractor and employer. It is important that the relevant provisions in the instructions in relation to monitoring be applied in a consistent manner and if monitoring instructions are substantially poor, they should be revisited".

On the issue of timely payment to contractor by government, $71.1 \%$ of the respondents observed that contractors were never paid on time and this too has a bearing on the performance of the contractor as noted by one of the respondents that: "the biggest challenges road contractors are facing is delayed payment. Certificates are approved and submitted but payment takes up to six (6) months to go through. Without adequate cash flow contractors cannot pay suppliers of materials and workers leading to projects stalling".

The research findings further revealed that the majority, $96.3 \%$, agreed that there are no clear dispute resolution procedures for road projects. One of the respondents noted that "It is true there are dispute resolution procedures; in case any party is aggrieved or if they are there they are not followed by UNRA".

On management of records the findings revealed that the $94 \%$ of the respondents agreed that there is poor record management on road projects. One of the respondents noted that: "In all audits conducted by the PPDA in government agencies, the biggest problem is availability of contract management records, Section 41 of the PPDA Act, 2003 requires maintenance of procurement records for a period of seven years from the date of award or termination of the procurement or disposal and failure to archive records contravenes the legal requirement of keeping procurement records for at least seven years before deposing them off.

Some of the challenges in records management at UNRA mentioned by the respondents include; lack of awareness of the importance of proper records management practices; failure to implement UNRA records management policy and procedures; big volumes of older stored records (mainly physical records); very limited space for the physical records and lack of training in records management.

The findings also revealed that the $72.3 \%$ of the respondents agreed the contract supervisors' failure to prepare monitoring plans. This finding concurs with [24] who noted that it is essential to development of a contract monitoring plan to ensure the contract is well monitored

Furthermore, majority of the respondents $(77.7 \%)$ noted that project expecta- 
tions are not clearly communicated to contractors. one of the respondents noted that "Most projects do not achieve their intended goals because the entities do not clearly communicate expectations which is bound to be disputes". In addition, $91.5 \%$ of respondents indicated that there is lack of a clear feedback mechanism between the contractor and employer on road projects yet feedback is an important component on project success. One of the respondents noted that "concerted effort should be made to facilitate communications between all project members, not just the client and contractor but also the other stakeholders' i.e. the public".

Sixty nine percent (69\%) of the respondents disagreed that technical audits are conducted during project implementation. This is emphasized by one of the respondents who mentioned that "although technical audits are critical on road projects, UNRA lacks the finances, personnel and equipment to conduct these audits. He noted that UNRA since its inception has conducted only two technical audits and these were done by hired experts from Kenya and Tanzania".

The respondents were also asked whether there is quality service delivery and there was a mixed reaction with $45 \%$ agreeing to the statement. One of the respondents indicated that "there have been a lot of delays by the road contractors and so the general public is unhappy. To make matters worse, some of the contractors being awarded contracts have already been branded as inefficient".

The respondents were asked whether there is proper contract monitoring in UNRA' in the procurement unit, $23 \%$ of the respondents strongly disagreed and $35 \%$ strongly agreed and $16 \%$ were not sure. This confirms that a well-designed contractor monitoring process based on efficiency as laid down in the institutional theory is the way to go. There is need to build internal capacity at UNRA to conduct contractor monitoring and reduce on use of hired consultants who are costly and on several occasions was bringing down the reputation of the organization.

The respondents were asked whether there is proper contract coordination in UNRA and their responses indicated that $51 \%$ of the respondents strongly disagreed, $9 \%$ disagreed, $21 \%$ were not sure, $09 \%$ agreed and $10 \%$ strongly agreed. In relation to the above one of the respondents noted that "UNRA staff coordinate all our contracts in the best manner possible, however, sometimes we are let down by certain factors. He cited delays in paying contractors and compensating land owners as one of the key factors in project delays". This is supported by the research findings were the $44 \%$ of the respondents strongly disagreed, $16 \%$ disagreed, $10.0 \%$ were non-committal, $20 \%$ agreed and $10 \%$ strongly agreed about the proper contract supervision in UNRA.

The results show there is a positive significant relationship at 0.000 between contractor monitoring and performance of road infrastructure projects. Therefore, improvement on the contractor monitoring will lead to a significant improvement of performance of road infrastructure projects.

\section{Regression Analysis}

Further analysis using regression analysis technique was made to check the level 
of influence of contractor monitoring on performance and results are shown in the Table 3 below.

The results in Table 4 indicate that there is a simple correlation between contractor monitoring and performance. The $\mathrm{R} 2$ value indicates how much of the dependent variable, performance can be explained by the independent variable contractor monitoring. In this case, 0.159 can be explained, which is very large. The standard error of the estimate is 0.1204 and the adjusted $\mathrm{R}$ square value is 0.841 . Therefore the adjusted square value of 0.841 implied that contractor monitoring predicts performance of road infrastructure projects; in other words performance of road infrastructure projects is dependent on contractor monitoring by $84.1 \%$.

Table 5 indicates that the regression model predicts the outcome variable significantly well. This indicates that the statistical significance of the regression model was applied. The $P<0.0005$ is less than 0.05 and this indicates a significant relationship in predicting the outcome variable. F-value of 31.223 is greater than the critical F-value of 6.90 at the 0.01 level of significance. Contractor

Table 3. Relationship between contractor monitoring and performance.

\begin{tabular}{|c|c|c|c|}
\hline \multicolumn{4}{|c|}{ Correlations } \\
\hline & & Contractor Monitoring & Performance \\
\hline \multirow{3}{*}{ Contractor monitoring } & Pearson Correlation & 1 & $0.274^{\star}$ \\
\hline & Sig. (2-tailed) & & 0.000 \\
\hline & $\mathrm{N}$ & 172 & 172 \\
\hline \multirow{3}{*}{ Performance } & Pearson Correlation & $0.274^{*}$ & 1 \\
\hline & Sig. (2-tailed) & 0.000 & \\
\hline & $\mathrm{N}$ & 172 & 172 \\
\hline
\end{tabular}

${ }^{\star *}$ Correlation is significant at the 0.01 level (2-tailed). Source: primary data. $\mathrm{N}=172$.

Table 4. Regression analyzing the relationship between the contractor monitoring and performance.

Model Summary

\begin{tabular}{ccccc}
\hline Model & $\mathrm{R}$ & R Square & Adjusted R Square & Std. Error of the Estimate \\
\hline 1 & $0.399^{\mathrm{a}}$ & 0.159 & 0.841 & 0.1204 \\
\hline
\end{tabular}

${ }^{\mathrm{a} P r e d i c t o r s: ~(C o n s t a n t), ~}{ }^{\mathrm{b}}$ Contractor Monitoring.

Table 5. Analysis of variance table for contractor monitoring and performance

ANOVA

\begin{tabular}{ccccccc}
\hline & Model & Sum of Squares & df & Mean Square & F & Sig \\
\hline \multirow{3}{*}{1} & Regression & 30.141 & 3 & 10.047 & 25.537 & $0.000^{\mathrm{a}}$ \\
Residual & 46.818 & 119 & 0.393 & & \\
Total & 76.959 & 122 & & \\
\hline
\end{tabular}

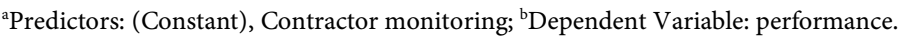


monitoring, therefore, predicts performance of road infrastructure projects. This implies that there is a positive relationship between contractor monitoring and performance of road infrastructure projects. The above proves that contractor monitoring influences performance of road infrastructure projects. The alternative hypothesis is therefore upheld.

\section{Discussion of Results}

Findings revealed that there is a positive significant relationship between contractor monitoring and performance of road infrastructure projects. This indicated that staff designated to monitor contractors lack adequate supervisory skills. Sometimes work is poorly supervised and this follows the fact that the general public has several times complained about the poor state of newly constructed roads because some roads get in a bad state a few months after construction. For example, Entebbe road, Nasser road, Oluyo-Packwach-Arua, Hima-Kasese, Kasese-Katunguru, Busega-Masaka, Jinja-Kampala etc. The general public has criticized the poor construction of Busega-Masaka, Jinja-Kampala roads where a few months after completion the roads developed potholes. This finding concurs with the study [24] who noted that best practices in government: components of an effective contract monitoring system have been a responsibility of different portfolio managers to determine the cost savings and other effects of procurement on their own.

The ability to realize procurement goals has been a fiasco in most road construction projects due to poor contractor monitoring in spite of UNRA contracting international road supervision Consultants. There are gross delays of roads construction completion and shoddy work in Uganda. This has, therefore, created contract monitoring gaps in terms of acting in stake holder interests, client/employer communication, negotiation, contract management, dispute resolution and approvals of changes and authorization [20] in his study on the 'critical success factors in government contract management' noted that qualified workforce, clear processes, relationships, resources, leadership and policies as critical success factors for contract management. All these have a direct impact on an organization's contract management process as well as resulting outcomes.

[2] noted that contract monitoring is essential for achieving the most profitable benefits from supplier relationships and to optimize total costs of the procurement function. However, when a party is aggrieved he/she can seek administrative review [25] defines administrative review as a clear dispute resolution procedures for road projects. This is asserted by [26] that in a theoretical underpinning of the challenges of contractor monitoring in Canada, the important issue in monitoring a supplier's performance is deciding who is best placed to actually monitor that performance. The supplier's performance must be assessed objectively against criteria that are pre-determined, clearly understood and agreed upon by both parties in the conditions of the contract so that the party does not seek administrative review. 
Furthermore regarding quality service delivery, $65 \%$ of the respondents appreciated that UNRA's mandate is not an easy task. The public expects quite a lot from the institution irrespective of the constraints it may face. UNRA is a young institution that faces an enormous assignment of developing and maintaining our roads and ensuring they are in a better condition. This is consistent with [27] finding that the main aim of contract monitoring is to ensure that goods or services are delivered on time, at the agreed cost. This implies developing effective working relationships with your suppliers, ensuring effective service delivery and providing consistent quality for stakeholders and end users [28]. The primary goal for contractor monitoring within any company is to ensure that commitments and obligations to customers and suppliers are clearly visible to the relevant people in the organization and that they are executed upon [27]. Contracts are used to control virtually every part of the trading relationship between buyers, sellers, and intermediaries, and have an impact on various functions within the enterprise [2]. For example, the sell-side involves sales, marketing, finance, legal, sales operations and customer service.

The findings further revealed that the lowest bid acquisition in UNRA has encouraged underperformance by the contractors who are in competition with other low-bid contractors. Under the low-bid acquisition methods used by UNRA, sometimes, contractors under price a bid in order to win a contract. To recover their lost profits, contractors then use substandard materials, poor workmanship, and take great risks to the health and safety of their laborers. Lowest bid contracting used by UNRA on roads has paved way to contracting poor contractors who perform shoddy work. According to [28] effectiveness of contract management in Austria requires the systematic management of contract creation, execution, compliance and analysis to maximize performance and minimize risk. With the increase in the complexity of doing business in public entities, coupled with the increase in transaction volumes and value in an ever tightening regulatory framework, it has resulted in businesses taking note of the importance of proper monitoring of contractor [8].

It was observed that at the procurement stage, some companies have also often been quoting lower bids, however, after winning the contracts they seek for variations causing the cost overrun. Contractor monitoring is the active control of the contract between the procuring and disposing entity and the contractor, in order to ensure delivery of a cost effective and reliable service at an agreed standard and price. It is the final stage in the bidding process and marks the beginning of a contractual relationship between the procuring and disposing entity and contractor in the process of managing and administrating the contract implementation [29]. Contractor monitoring cycle is the process of systematically and efficiently managing contract creation, execution and analysis for maximizing operational and financial performance and minimizing risk [30] while [31] his study on compliance monitoring and procurement performance carried out in Uganda, notes that supplier/contractor monitoring has slowly become an important component for effective supplier relationship management that is di- 
rectly linked to securing the supply of key commodities needed for sustaining business.

The reports from UNRA further confirmed that although project unit cost for road construction projects greatly varied from project to project, the average cost per $\mathrm{km}$ of double bituminous surface treatment upgrading works had reduced from UGX 2.05 billion to UGX 1.84 billion. A total of $1255 \mathrm{~km}$ roads were upgraded/rehabilitated/reconstructed, and over $20,000 \mathrm{kms}$ received periodic and routine maintenance mainly by private local contractors [23].

Findings reveal that there was delayed completion of works by the contractor for over 10 weeks without the employer's intention to charge for delayed damages. This is noted on the Kawempe-Kafu Road (166 Km) by M/s Energoprojekt Niskogradnja at UGX. 140,556,490,385. Notwithstanding the above findings, UNRA disregarded a recommendation in the FY 2008/09 audit report to defer application of the overlay since underlying layers were weak; more than UGX.140,556,490,385 was to be spent yet the works had shown signs of distress [17].

[14] investigated the causes of construction project delays and cost overruns in Uganda's public sector with an intention of ranking them according to their frequency, severity and importance. A total of 30 projects at Civil Aviation Authority were reviewed. Five most important causes of delays and cost overruns were found to be changes in the work scope, delayed payments to contractors, poor monitoring and control, high inflation and interest rates. [29] examined the relationship between supplier opportunism, contract management and service delivery in outsourced contracts in Uganda. The study was conducted in the 116 Procuring and Disposing Entities in Uganda and the findings reveal that supplier opportunism and contract management are significant predictors of service delivery. This study, however, does not address the impact of supplier determination process on contract performance.

It was observed that the coordination of contracts involves many activities to ensure the fulfillment of a contract. This covers those activities or events that can alter or disrupt the performance of a contract e.g., default of a contractor, disputes and contract amendments. Whenever the satisfactory fulfillment of a contract is jeopardized, UNRA sometimes takes the necessary steps to serve and protect the interests of the institution in meeting the terms of the contract, and then to protect (where appropriate) the interests of other parties involved in the contract.

\section{Conclusions, Recommendations and Policy Implications}

For effective road infrastructure delivery and performance, there is need to build strong contract monitoring mechanisms. These should target the performance of contractors and contract managers/supervisors. With skilled personnel proper contract monitoring practices shall be enforced. In contract monitoring some of the components and practices include skills development, policy development, plans, communication, payments, management of records, contractor appraisal, 
inspections and audits and dispute resolution. This study found out that if these contract monitoring components are well managed, there is a very high possibility of having a viable road infrastructure project that will guarantee a sound business success and effective service delivery.

In order to improve contractor monitoring and performance of road infrastructure projects the researcher makes the following recommendations:

The procurement rules should be adjusted to allow best value contracting method, such as award contracts based on demonstrated past performance, technical and managerial merit, technical innovation, and financial health over and above the contractor's price.

All contractors monitoring should be done by appropriately qualified personnel with competence and experience in road projects.

Uganda National Roads Authority should adopt systems that appraise both contractors and contract supervisors with clear disciplinary actions for unsatisfactory performance, professionalize management of records and develop a records management code of ethics, establish a clear chain of communication to ensure timely input and distribution on the projects and undertake technical audits to enhance the quality of road construction. These should be conducted by the qualified professional engineers with experience in highway designing, construction and contract management.

The Government should allocate adequate financial resources to UNRA to ensure timely payment of contractors to enhance timely services delivery and also consider setting up an Independent Public Infrastructure Development and Monitoring Unit with specialized skills to provide support in Road infrastructure planning, procurement monitoring.

The researcher theorises that one critical area could be due contractor monitoring and no deliberate effort has been made by researchers to link contractor monitoring to the performance of the road projects in Uganda. This has created a knowledge gap.

\section{References}

[1] Benamghar, L. and Limi, A. (2011) Efficiency in Public Procurement in Rural Road Projects in Nepal. World Bank Policy Research Working Paper No. 5736. https://doi.org/10.1596/1813-9450-5736

[2] Arrows, S. (2010) Horizontal Policies in Public Procurement. Journal of Public Procurement, 10, 149-186.

[3] Wasike, W.S. (2001) Road Infrastructure Policies in Kenya: Historical Trends and Current Challenges. Kenya Institute for Public Policy Analysis Working Paper No. 1, Nairobi.

[4] Orr, J. and Kennedy, R. (2008) Highlights of Recent Trends in Global Infrastructure: New Players and Revised Game Rules. Transnational Corporations, 17, 95.

[5] KPMG (2013) International Annual Review. https://home.kpmg.com/content/dam/kpmg/pdf/2013/12/international-annual-revi ew-2013.pdf

[6] Deustche Bank (2012). 
https://annualreport.deutsche-bank.com/2012/ar/servicepages/downloads/files/dbfy 2012_entire.pdf

[7] World Bank (2011) Comparative Analysis of Public Finance Management Reforms. World Bank, Washington DC.

[8] Bagaka, O. and Kobia, M. (2010) Enhancing Trust and Accountability in Government. CAPAM African Regional Conference, Abuja, 18 May 2010.

[9] Barasa, H. (2014) Procurement Practices Affecting Effective Public Projects Implementation in Kenya; A Case Study of Kenya Civil Aviation Authority. European Journal of Business and Management, 6, 49.

[10] Banaitiene, N. and Banaitis, A. (2006) Analysis of Criteria for Contractors. Taylor and Francis Group, Abingdon-on-Thames, 276-282.

[11] UNRA (2008) 5 Year Strategic Plan. UNRA, Kampala.

[12] ACODE (2012) Assessing Governance Aspects in the Water and Roads Sectors in Uganda. ACODE, Kampala.

[13] Inspectorate of Government (2012) The Third Annual Report on Tracking Corruption Trends in Uganda Using the Data Tracking System. Kampala.

https://www.igg.go.ug/static/files/publications/Third_DTM_Report_Final_12Dec20 12_2_1.pdf

[14] Ministry of Works and Transport (2011) Annual Performance Review Report. Kampala.

[15] Alinaitwe, H., Apolot, R. and Tindiwensi, D. (2013) Investigation into the Causes of Delays and Cost Overruns in Uganda's Public Sector Construction Projects. Journal of Construction in Developing Countries, 18, 33-47.

[16] Uganda Road Fund (2015) Road Maintenance Monitoring Report. Kampala.

[17] Office of the Auditor General (2010) Annual Report. Kampala.

[18] Kasaija, M. (2015) Budget Speech Financial Year 2015/16. Ministry of Finance, Planning and Economic Development, Kampala.

[19] Muhakanizi, K. (2005) The State of Public Service Delivery in Uganda; Achievements Challenges and Measures for Better Service Delivery. Serena International Conference Centre, Kampala.

http://budget.go.ug/budget/sites/default/files/PSST\%20Presentation\%20on\%20\%20 Service\%20Delivery.pdf

[20] Rendon, R. (2010) Critical Success Factors in Government Contract Management. http://www.ippa.org/IPPC4/Proceedings/19Others/Paper19-2.pdf

[21] Oluka, P. and Basheka, B. (2014) Determinants and Constrains to Effective Procurement Contract Management in Uganda; A Practioner's Prespective. International Journal of Logistics Systems and Management, 17, 104-124. https://doi.org/10.1504/IJLSM.2014.057983

[22] Booth, D. and Mutebi, F.-G. (2015) Reforming the Roads Sector in Uganda; A Six Year Retrospective.

[23] Ssebanakitta, P. (2013) Impact of Procurement Reforms on Procurement of Works in Uganda. Journal of Public Procurement and Contract Management, 110-105.

[24] Hinton (2003) Best Practices in Government: Components of an Effective Contract Monitoring System.

[25] PPDA (2015) Administrative Review Guidelines. Kampala.

[26] Hansson, S.O. (2013) Decision Theory: A Brief Introduction. Department of Philosophy and the History of Technology, Royal Institute of Technology, Stockholm. http://people.kth.se/ soh/decisiontheory.pdf 
[27] Schmitz, J. and Platts, K. (2004) Supplier Logistics Performance Measurement: Indications from a Study in the Automotive Industry. International Journal of Production Economics, 89, 231-243.

[28] Hatush, Z. and Skitmore, M. (2009) Evaluating Contractor Prequalification Data: Selection Criteria and Project Success Factors. Construction Management Economics, 15, 129-147.

[29] Ahimbishibwe, A. and Muhwezi, M. (2015) Contract Management, Inter Functional Coordination, Trust and Contract Performance of Works Contracts in Ugandan Public Procuring and Disposing Entities. European Journal of Business and Management, 7.

[30] Sabiiti, C.K., Muhumuza, E. and Basheka, B.C. (n.d.) Developing Public Procurement Performance Measurement Systems in Developing Countries: The Uganda Experience. International Public Procurement Conference. http://www.ippa.org/IPPC4/Proceedings/12ProcurementPerformance/Paper12-1.pdf

[31] Mbalangu, G. (2015) Supply Chains: Some Doubts. International Purchasing and Supply Education and Research Association. Cardiff.

\section{Scientific Research Publishing}

\section{Submit or recommend next manuscript to SCIRP and we will provide best} service for you:

Accepting pre-submission inquiries through Email, Facebook, LinkedIn, Twitter, etc. A wide selection of journals (inclusive of 9 subjects, more than 200 journals)

Providing 24-hour high-quality service

User-friendly online submission system

Fair and swift peer-review system

Efficient typesetting and proofreading procedure

Display of the result of downloads and visits, as well as the number of cited articles

Maximum dissemination of your research work

Submit your manuscript at: http://papersubmission.scirp.org/

Or contact jbcpr@scirp.org 